\title{
Effect of intimate partner violence of women on minimum acceptable diet of children aged 6-23 months in Ethiopia: evidence from 2016 Ethiopian demographic and health survey
}

\author{
Desta Melaku Tsedal ${ }^{1 *}$, Mezgebu Yitayal' ${ }^{2}$ Zegeye Abebe $^{3}$ and Adino Tesfahun Tsegaye ${ }^{4}$
}

\begin{abstract}
Background: The absence of proper infant and young child feeding practice results in malnutrition. Intimate Partner Violence (IPV) is potentially a major factor affecting child feeding practices. However, there is limited evidence about the effect of intimate partner violence (IPV) on a minimum acceptable diet. Therefore, in this study, we hypothesized that IPV will be associated with a lack of a minimum acceptable diet among children aged 6-23 months.

Methods: We conducted a cross-sectional analysis using the Ethiopian Demographic and Health Survey (EDHS) 2016. All child-mother pairs that participated in EDHS 2016 from all regions of Ethiopia were included. The analysis included mother-child pairs where 6-23 months aged children with mothers who were ever in a committed partnership and interviewed for domestic violence were involved. The data were weighted considering enumeration areas as a cluster and place of residence as a stratum. A binary logistic regression analysis was done to identify factors independently associated with a minimum acceptable diet

Result: Totally, 1307 observations were included in the final analysis. The mean age of mothers was 29 years (standard deviation \pm 6.54 years), the mean age of children was $14 . \pm 5.02$ months, and $32 \%$ of women had intimate partner violence (IPV). Of the children, 8\% had a minimum acceptable diet (minimum acceptable diet), 15\% had a minimum dietary diversity, and $43 \%$ had a minimum meal frequency. Having intimate partner violence decreases children minimum acceptable diet by $65 \%$ (AOR: $0.35 ; 95 \% \mathrm{Cl}: 0.16,0.77$ ). The other factors associated with the minimum acceptable diet were caregivers attaining a secondary level of education (AOR: 4.01; 95\% Cl: 1.04, 15.45), currently working (AOR: 2.26; 95\% Cl: 1.01, 5.11), and undecided fertility desire (AOR: 4.72; 95\% Cl: 1.37, 16.28).

Conclusion: Intimate partner violence against women had a negative association with the minimum acceptable diet children have received. Decreasing violence against women, educating, and increasing work opportunities for them would help in improving child feeding practice and reducing malnutrition and its consequences. Further studies that focus on possible community-based interventions aiming to decrease IPV are recommended.
\end{abstract}

Keywords: Children, Ethiopia, Intimate partner violence, Minimum acceptable diet

\footnotetext{
* Correspondence: leouldesti@gmail.com

'Department of Anesthesia, School of Medicine, University of Gondar,

College of Medicine and Health Sciences, Gondar, Ethiopia

Full list of author information is available at the end of the article
}

(c) The Author(s). 2020 Open Access This article is licensed under a Creative Commons Attribution 4.0 International License, which permits use, sharing, adaptation, distribution and reproduction in any medium or format, as long as you give appropriate credit to the original author(s) and the source, provide a link to the Creative Commons licence, and indicate if changes were made. The images or other third party material in this article are included in the article's Creative Commons licence, unless indicated otherwise in a credit line to the material. If material is not included in the article's Creative Commons licence and your intended use is not permitted by statutory regulation or exceeds the permitted use, you will need to obtain permission directly from the copyright holder. To view a copy of this licence, visit http://creativecommons.org/licenses/by/4.0/. The Creative Commons Public Domain Dedication waiver (http://creativecommons.org/publicdomain/zero/1.0/) applies to the data made available in this article, unless otherwise stated in a credit line to the data. 


\section{Background}

For proper growth and development, children should receive the minimum acceptable diet including recommended quality and quantity of foods according to their age [1, 2]. Yet, over 150 million children are undernourished globally [3]. In Ethiopia, 38\% of children under the age of 5 are short for their age, 10\% are thin for their height, and 24\% are thin for their age [4]. Most of the burden of childhood undernutrition can be explained by the absence of proper infant and young child feeding practices during the first two years $[5,6]$. Child age, parity of mothers, child illness, maternal knowledge [7], the attitude of mothers [8], parental educational attainment, and household income are some of the factors that affect child feeding practices [9].

Intimate Partner Violence (IPV) is potentially a major factor affecting child feeding practices. IPV is a significant social and public health problem affecting $30 \%$ of ever-partnered women worldwide [10]. In Ethiopia, the cumulative incidence of IPV was $28 \%$ in a lifetime, and $20 \%$ in the past 12 months [4]. Women are the primary caregivers of children and violence affecting women might have an effect on child feeding practice. Violence is associated with mental health problems [11], and women who are depressed and anxious are more likely to abstain from breastfeeding and childcare [12]. Physical and psychological effects of IPV impair women's ability to breastfeed and provide other complementary foods [13-17].

Previous studies focused on the effect of IPV on breastfeeding only and did not address the effect of IPV on the minimum acceptable diet. Continued investments in nutrition-specific interventions to avert child undernutrition through community engagement and women's empowerment are recommended to accelerate progress in countries with the highest burden of child undernutrition and mortality [18]. Therefore, in this study, we hypothesized that maternal exposure to IPV will be associated with a lack of minimum acceptable diet among children aged 6-23 months, providing an indication that reduction in IPV may reduce childhood malnutrition.

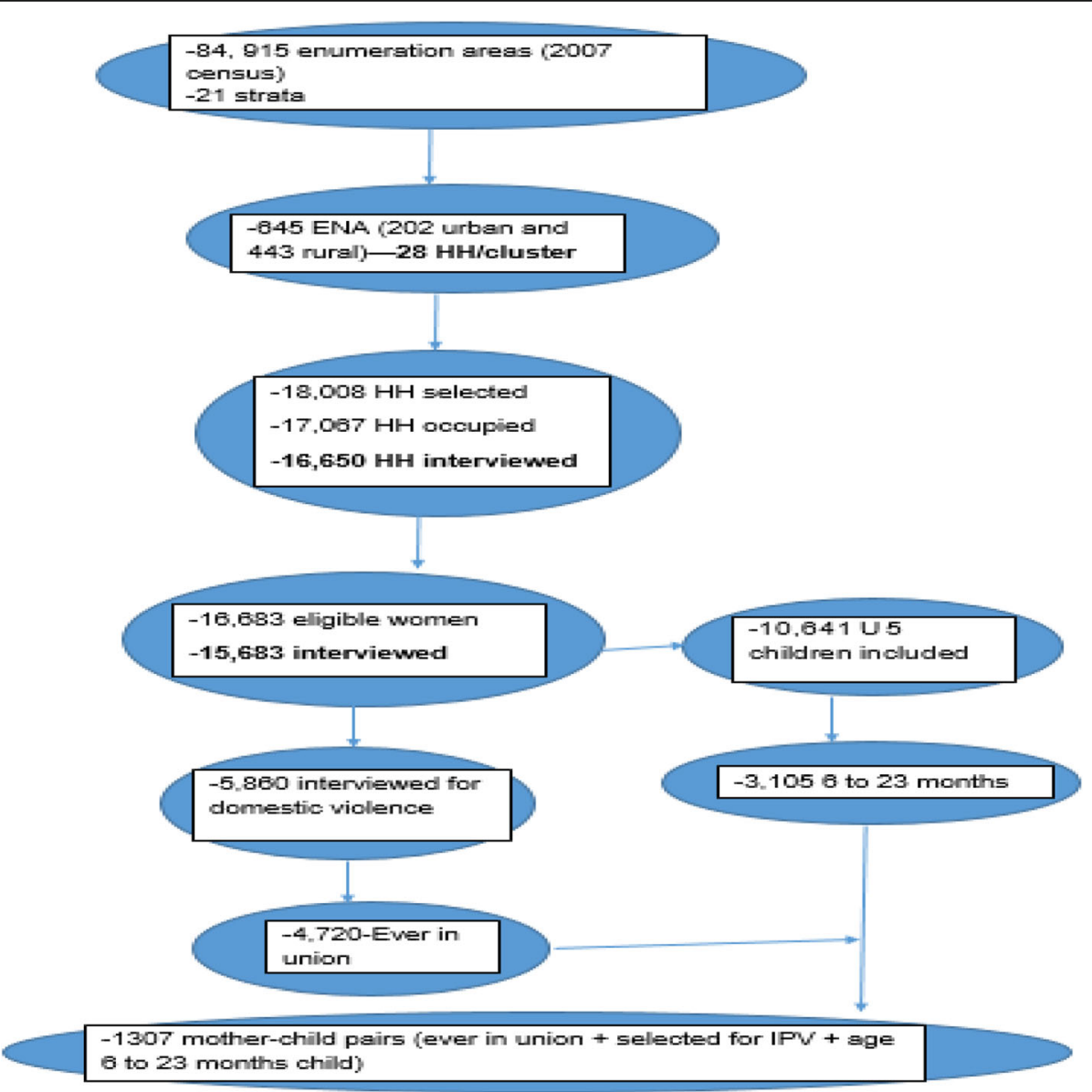

Fig. 1 Flow chart showing the study procedure 


\section{Methods}

\section{Study setting and population}

We conducted a cross-sectional analysis using the Ethiopian Demographic and Health Survey (EDHS) 2016. All childmother pairs that participated in EDHS 2016 from all regions of Ethiopia were included. The analysis included mother-child pairs where 6-23 months aged children with mothers who were ever in a committed partnership and interviewed for domestic violence were involved.

\section{Sample size and sampling procedure}

For EDHS 2016, the census frame was a complete list of 84,915 enumeration areas (EAs) created for the 2007 census. Each region was stratified into urban and rural areas and samples of EAs were selected in each stratum in two stages. In the first stage, a total of EAs were selected with probability proportional to EA size, and a household listing operation was performed in the selected EAs. The resulting lists of households served as a sampling frame for the selection of households in the second stage. Details of the recruitment of study participants found elsewhere [4]. From the involved households, 15,683 women completed the interview, and 5860 of them were interviewed for domestic violence. Only one eligible woman per household was randomly selected for domestic violence interview, and it was omitted if privacy could not be obtained. There were 10,641 children under the age of 5 and 3105 of them were in the age group between 6 and 23 months.

\section{Data collection procedures and quality control}

The EDHS is a standardized report prepared from data collected using standardized tools. The data were collected through face-to-face interviews with the child's mothers/ caregivers. The 2016 EDHS questionnaires have parts divided into three; households, woman's, and man's questionnaires. Primary caregivers were interviewed to get data about the household and children. Generally, the questionnaires capture information on socio-demographic variables, reproductive health issues, domestic violence, health service characteristics, and others. The woman's questionnaire had parts for children, which capture information on child immunization, health, and nutrition. The dietary diversity data were collected using a 24-h recall method; that is, mothers were asked to recall all foods given to their child in the past twenty-four hours before the survey.

\section{Variables of the study}

The outcome of interest was getting minimum acceptable diet and the primary exposure was maternal exposure to intimate partner violence. The covariates considered were child characteristics (age in months, birth order, child sex); healthcare characteristics (place of delivery, number of antenatal visits, PNC counseling); parental characteristics (mother's age, place of residence, father's education, mother's marital status, mother's work status); household characteristics (wealth index, number of children under the age of 5 , exposure to media).

Minimum dietary diversity (MDD) was defined as the proportion of children aged 6-23 months who received foods minimum acceptable diet from four or more food groups out of the seven food groups during the previous day/ within $24 \mathrm{~h}[9,19]$. The seven food groups are the following: starchy staples (foods minimum acceptable diet from grain, roots, or tubers); 2) legumes and nuts; 3 ) dairy products (milk other than

Table 1 Sociodemographic and economic characteristics of parents of children aged 6 to 23 months in Ethiopia, EDHS 2016

\begin{tabular}{llll}
\hline Variables & \multicolumn{2}{l}{ Intimate partner violence } & \multirow{2}{*}{ Total } \\
\cline { 2 - 3 } & Yes & No & N (\%) \\
\hline $15-19$ & $5(1)$ & N (\%) & \\
$20-24$ & $90(21)$ & $44(5)$ & $49(4)$ \\
$25-29$ & $119(28)$ & $272(31)$ & $392(30)$ \\
$30-34$ & $101(24)$ & $196(22)$ & $297(23)$ \\
$35-39$ & $72(17)$ & $128(14)$ & $199(15)$ \\
$40-44$ & $27(6)$ & $49(6)$ & $76(6)$ \\
$45-49$ & $7(2)$ & $9(1)$ & $16(1)$
\end{tabular}

Residence

$\begin{array}{llll}\text { Urban } & 33(8) & 118(13) & 151(11) \\ \text { Rural } & 388(92) & 768(87) & 1156(88) \\ \text { Maternal education } & & & \\ \text { No education } & 271(64) & 539(61) & 810(62) \\ \text { Primary } & 120(29) & 260(29) & 380(29) \\ \text { Secondary } & 19(4) & 56(6) & 75(6) \\ \text { Higher } & 11(3) & 31(4) & 42(3)\end{array}$

Religion

$\begin{array}{llll}\text { Orthodox } & 140(33) & 323(36) & 463(35) \\ \text { Protestant } & 96(23) & 192(22) & 289(22) \\ \text { Muslim } & 164(39) & 355(40) & 519(40) \\ \text { Others } & 20(5) & 16(2) & 36(3)\end{array}$

Household Wealth Index

$\begin{array}{llll}\text { Poorest } & 119(28) & 183(21) & 302(23) \\ \text { Poorer } & 94(22) & 196(22) & 289(22) \\ \text { Middle } & 95(23) & 185(21) & 280(21) \\ \text { Richer } & 71(17) & 175(20) & 246(19) \\ \text { Richest } & 42(10) & 147(17) & 189(14)\end{array}$

Father's educational status

\begin{tabular}{llll} 
No education & $201(48)$ & $417(47)$ & $618(47)$ \\
Primary & $189(45)$ & $330(37)$ & $519(40)$ \\
Secondary & $23(6)$ & $89(10)$ & $112(9)$ \\
Tertiary & $8(2)$ & $50(6)$ & $58(4)$ \\
\hline
\end{tabular}


breast milk, cheese, or yogurt); 4) Flesh foods (meat, fish, poultry and liver/organ meats; 5) vitamin A-rich fruits and vegetables (pumpkin; red or yellow yams or squash; carrots or red sweet potatoes; green leafy vegetables; fruits such as mango, papaya, or other local vitamin Arich fruits); 6) other fruits and vegetables (or fruit juices); 7) eggs. Minimum meal frequency (MMF) was defined as [1] at ages $6-8$ months, the child was breastfed and received two or more daily feedings of solid, semi-solid or soft foods; or [2] at ages 9 to 23 months, the child was breastfed and received three or more daily feedings of solid, semi-solid or soft foods; or [3] at ages 6 to 23 months, the child was not breastfed and received four or more daily feedings of solid, semi-solid, or soft foods. Minimum acceptable diet: A child was considered to receive at least the minimum acceptable diet for health if the MDD and the MMF criteria were met.

Intimate partner violence was defined as ever in committed partnership women who have experienced one or more of the specified acts of spousal physical violence or sexual violence or emotional violence by their current or most recent husbands/partners in the 12 months preceding the survey [20]. Intimate partner physical violence was defined as ever in committed partnership women who have experienced one or more of the specified acts of spousal physical violence by their current or most recent husbands/partners in the 12 months preceding the survey. Likewise, intimate partner sexual violence and emotional violence were defined as ever experiencing one or more of the specified acts of spousal sexual or emotional violence by their current or most recent husbands/partners in the 12 months preceding the survey.

Exposure to mass media: in the EDHS 2016 survey, respondents were asked how often they read a newspaper, listened to the radio, or watched television. Those who were exposed to any of the media at least once a week were considered to have adequate media exposure.

\section{Data management and analysis}

The data were weighted considering enumeration areas as a cluster and place of residence as a stratum. Initial descriptive analyses provided general information on the characteristics of the study populations. A bivariate logistic regression analysis was done. Variables with $P$ value $<0.2$ were included in the multivariable logistic regression model to identify factors independently associated with a minimum acceptable diet.

A propensity score matching analysis was performed to identify the effect of intimate partner violence on a minimum acceptable diet. A propensity score was the probability of being exposed to the IPV, given a set of observed covariates (residence, mother educational status, wealth index, mother work status for the last 12 months, child desire, media exposure), and estimated using the logistic regression model. Nearest neighborhood matching was used in the analysis, which matches a given child of a woman who had intimate partner violence to a child of a woman who had no intimate partner violence whose propensity score is closest to that of the first subject or vice versa. The method is used to balance the two groups so that a direct comparison would be possible for evaluating the effects of intimate partner violence on the minimum acceptable diet. The average effect on children of women who had intimate partner violence was computed by averaging the difference between the outcomes of the two groups. The level of significance was defined at a $P$-value of less than 0.05 .

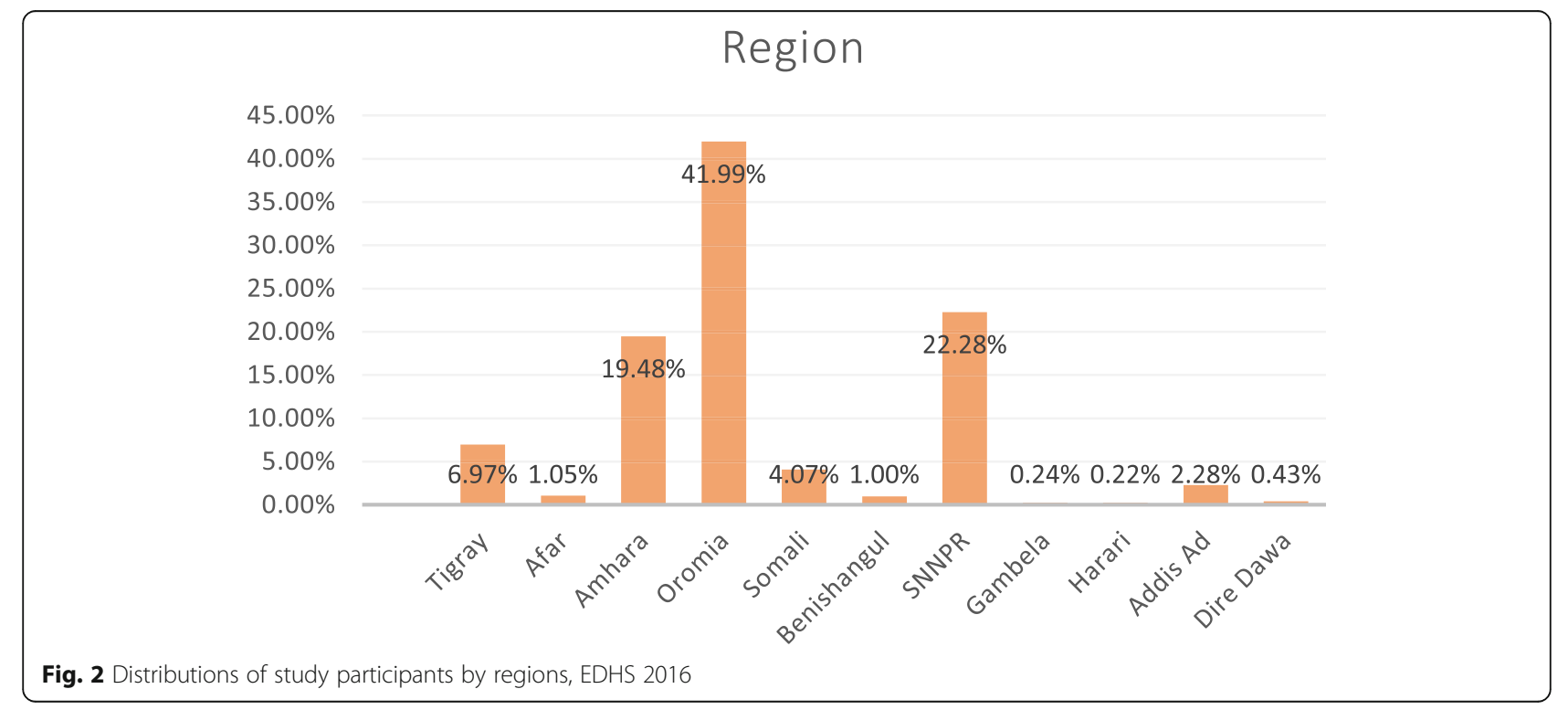




\section{Results}

Sociodemographic and economic characteristics of the study participants

Of the total 15, 683 women participating, 5860 completed the questionnaire for domestic violence. Of those 5860, 1313 had children aged 6 to 23 months. Excluding six participants who were never in a committed partnership, 1307 observations were included in the final analysis (Fig. 1). The mean age of mothers was 29 years (standard deviation \pm 6.54 years), $30 \%$ of the mothers were in the age group between 25 and 29 years, $88 \%$ were from rural areas, $62 \%$ had no formal education and $23 \%$ were in the 1 st wealth quantile (poorest). Also, $47 \%$ of the study participants' partners had no formal education (Table 1). Regarding regional composition, $42 \%$ of the study participants were from the Oromia region and only $0.22 \%$ were from Hariri region (Fig. 2).

\section{Reproductive characteristics of mothers/caregivers}

For women who had given birth, the mean parity was $4.10(\mathrm{SD} \pm 2.52)$ births. The age at marriage of $36 \%$ of the women were below 18 years, $56 \%$ of the women had

Table 2 Reproductive characteristics of mothers/caregivers of children aged 6 to 23 months in Ethiopia, EDHS 2016

\begin{tabular}{|c|c|c|c|}
\hline \multirow{2}{*}{$\begin{array}{l}\text { Variables } \\
\text { Children ever born }\end{array}$} & \multicolumn{2}{|c|}{ Intimate partner violence } & \multirow{2}{*}{$\begin{array}{l}\text { Total } \\
\text { N (\%) }\end{array}$} \\
\hline & $\begin{array}{l}\text { Yes } \\
\text { N (\%) }\end{array}$ & $\begin{array}{l}\text { No } \\
\text { N (\%) }\end{array}$ & \\
\hline 1 to 2 & $126(30)$ & $318(36)$ & $444(34)$ \\
\hline 3 to 4 & $93(22)$ & $256(29)$ & $348(27)$ \\
\hline$>=5$ & $202(48)$ & $313(35)$ & $515(39)$ \\
\hline \multicolumn{4}{|l|}{$\begin{array}{l}\text { Presence of other under } \\
\text { five children in the house }\end{array}$} \\
\hline No & $163(39)$ & $407(46)$ & $570(44)$ \\
\hline Yes & $258(61)$ & $479(54)$ & $737(56)$ \\
\hline \multicolumn{4}{|l|}{ Age at first birth } \\
\hline$<18$ & $150(36)$ & $315(36)$ & $466(36)$ \\
\hline $18-24$ & $244(58)$ & $492(56)$ & $736(56)$ \\
\hline $25-29$ & $24(6)$ & $63(7)$ & $87(7)$ \\
\hline$>=30$ & $3(1)$ & $15(2)$ & $18(1)$ \\
\hline \multicolumn{4}{|l|}{ Currently pregnant } \\
\hline No or unknown & 394 (94) & $837(95)$ & $1231(94)$ \\
\hline Yes & $27(6)$ & $49(5)$ & $76(6)$ \\
\hline \multicolumn{4}{|l|}{ Number of living children } \\
\hline$<=2$ & $134(32)$ & 347 (39) & $481(37)$ \\
\hline 3 to 4 & $116(27)$ & $281(32)$ & $396(30)$ \\
\hline$>=5$ & $171(41)$ & $258(29)$ & $429(33)$ \\
\hline \multicolumn{4}{|l|}{ Current Marital Status } \\
\hline Married & $396(94)$ & $855(96)$ & $1151(96)$ \\
\hline Living with partner & $7(2)$ & $15(2)$ & $22(2)$ \\
\hline Others $^{\mathrm{a}}$ & $18(4)$ & $17(2)$ & $35(2)$ \\
\hline \multicolumn{4}{|l|}{ Fertility desire } \\
\hline Want more children & $249(59)$ & $516(58)$ & 765 (59) \\
\hline Undecided & $26(6)$ & $41(5)$ & $67(5)$ \\
\hline Don't want more children & $146(35)$ & $329(37)$ & $475(36)$ \\
\hline \multicolumn{4}{|l|}{$\begin{array}{l}\text { Mother worked outside } \\
\text { home in the last } \\
12 \text { months }\end{array}$} \\
\hline No & $227(54)$ & $506(57)$ & $733(56)$ \\
\hline In the past year & $77(18)$ & $157(18)$ & $234(18)$ \\
\hline Currently working & $118(28)$ & $223(25)$ & $340[21]$ \\
\hline
\end{tabular}

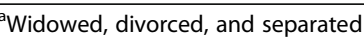


more than one child under the age of 5 years, and $6 \%$ of the women were pregnant during the survey (Table 2).

\section{Media exposure}

Almost one-fifth (20\%) of the participants had satisfactory media exposure. About 16\% of the participants had listened to the radio at least once a week (Fig. 3).

\section{Child-related characteristics}

The mean age of children was $14.15 \pm 5.02$ months with $37 \%$ between 12 and 17 months, 53\% were girls, 29\% were 6th and above in terms of their birth order (Table 3).

\section{Intimate partner violence}

Overall, $32 \%$ of the study participants experienced IPV with emotional violence as the most common type of IPV (Fig. 4).

\section{Feeding practice of children}

In this study, $8 \%$ of children received the recommended minimum acceptable diet. Among the children, 42\% were given the recommended meal frequency, and 14\% received the recommended minimum dietary diversity.

\section{Determinants of minimum acceptable diet}

In the multivariable analysis, level of education, mothers' work status, fertility desire, and intimate partner violence had a statistically significant association with a minimum acceptable diet. The odds of getting a minimum acceptable diet among children of mothers who had a secondary education was higher than those who did not have formal education (AOR: 4.01; 95\% CI:
1.04, 15.45). As compared to children of mothers who did not work for the last 12 months prior to the survey, children of mothers who were working during the survey had higher odds of getting a minimum acceptable diet (AOR: 2.26; 95\% CI: 1.01, 5.11). Children of mothers who didn't decide their fertility desire had higher odds of getting a minimum acceptable diet as compared to those who were children of mothers who decided not to have more children (AOR: 4.72; 95\% CI: 1.37, 16.28). Finally, children of mothers who had intimate partner violence had $65 \%$ lesser odds of getting a minimum acceptable diet as compared to those who were children of women who did not have an intimate partner violence (AOR: 0.35; 95\% CI: 0.16, 0.77) (Table 4).

\section{Discussion}

This study aimed to assess the effect of maternal/caregiver IPV exposure on getting the minimum acceptable diet among children aged 6 to 23 months. We found that maternal exposure to IPV was associated with a lower proportion of children receiving a minimum acceptable diet. Also, higher maternal level of education, mother/ caregivers' currently working, and desire for children had a statistically significant association with getting a minimum acceptable diet.

We found a large effect, with the proportion of children receiving a minimum acceptable diet declining by 65\% among families in which women experienced IPV. This implies that the effect of IPV exposure to mothers/ caregivers has the potential to pass to their children and lead them to develop malnutrition and related consequences. Knowing IPV as it has a compounded effect in affecting children's growth and development beyond its

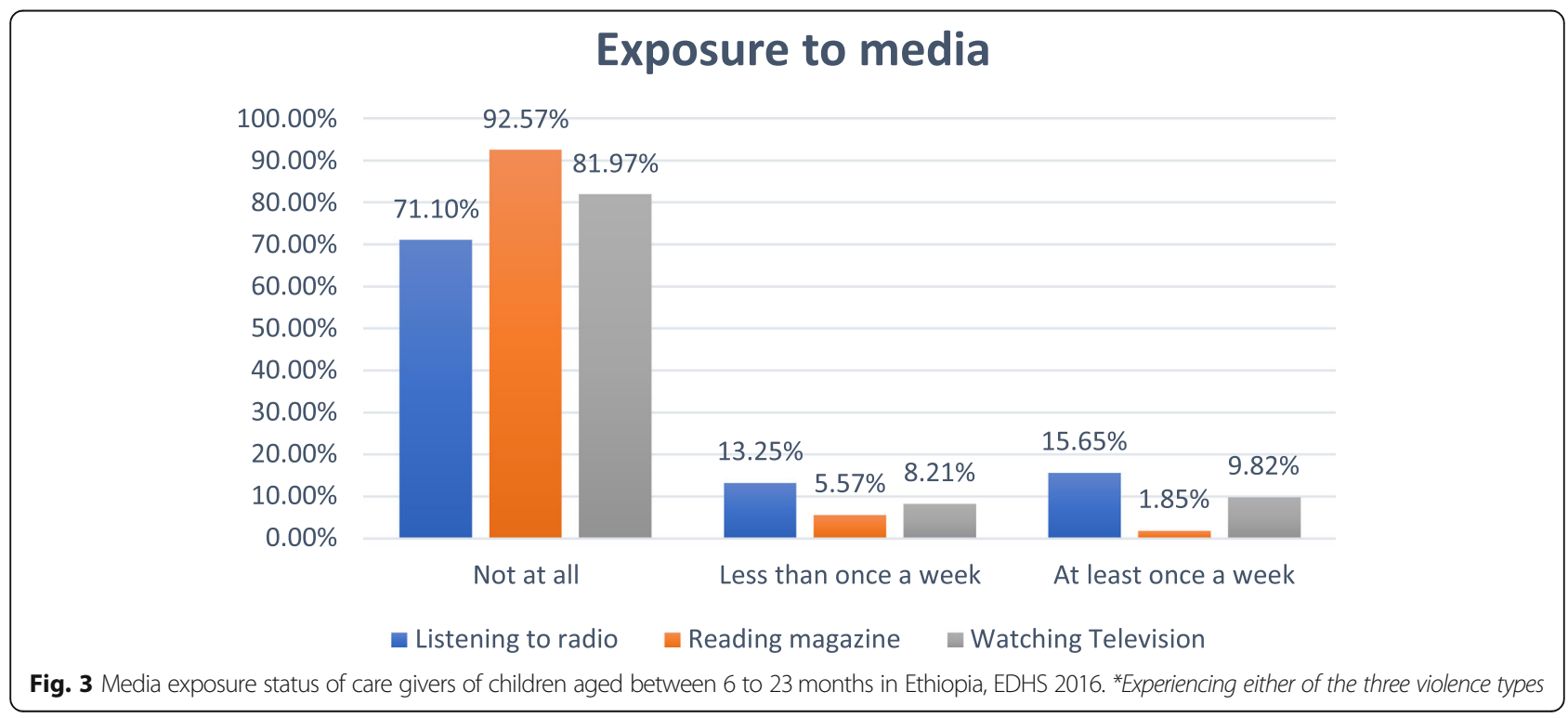


Table 3 Characteristics of children aged 6 to 23 months in Ethiopia, EDHS 2016

\begin{tabular}{|c|c|c|c|}
\hline \multirow{2}{*}{$\begin{array}{l}\text { Variables } \\
\text { Birth order }\end{array}$} & \multicolumn{2}{|c|}{ Intimate partner violence } & \multirow{2}{*}{$\begin{array}{l}\text { Total } \\
\text { N (\%) }\end{array}$} \\
\hline & $\begin{array}{l}\text { Yes } \\
\text { N (\%) }\end{array}$ & $\begin{array}{l}\text { No } \\
N(\%)\end{array}$ & \\
\hline First & $70(17)$ & $160(18)$ & $230(18)$ \\
\hline Second & $56(13)$ & $160(18)$ & $216(17)$ \\
\hline Third & $49(12)$ & $144(16)$ & $192(15)$ \\
\hline Fourth & $50(12)$ & $115(13)$ & $164(13)$ \\
\hline Fifth & $44(10)$ & $88(10)$ & $131(10)$ \\
\hline 6th and above & $153(36)$ & $221(25)$ & $374(29)$ \\
\hline \multicolumn{4}{|l|}{ Twin } \\
\hline No & $411(98)$ & $843(95)$ & $1254(96)$ \\
\hline Yes & $10(2)$ & $43(5)$ & $53(4)$ \\
\hline \multicolumn{4}{|l|}{ Sex of child } \\
\hline Male & $213(51)$ & $403(46)$ & $616(47)$ \\
\hline Female & $208(49)$ & $483(54)$ & $691(53)$ \\
\hline \multicolumn{4}{|l|}{ Birth interval } \\
\hline First birth & $70(17)$ & $164(19)$ & $234(18)$ \\
\hline Less than two years & $66(16)$ & $139(16)$ & $205(16)$ \\
\hline 2 to 5 years & $232(55)$ & $441(50)$ & $674(52)$ \\
\hline More than 5 years & $53(13)$ & $141(16)$ & $194(15)$ \\
\hline \multicolumn{4}{|l|}{ Child age in months } \\
\hline 6 to 11 months & $120(28)$ & $313(35)$ & $433(33)$ \\
\hline 12-17 months & $167(40)$ & $319(36)$ & $486(37)$ \\
\hline $18-23$ months & $134(32)$ & $254(29)$ & $388(30)$ \\
\hline \multicolumn{4}{|l|}{$\begin{array}{l}\text { Mother had ANC during } \\
\text { pregnancy of the child }\end{array}$} \\
\hline No & $167(40)$ & 334 (38) & $501(38)$ \\
\hline Yes & $254(60)$ & $552(62)$ & $806(62)$ \\
\hline \multicolumn{4}{|l|}{ Duration of breastfeeding } \\
\hline Ever breast fed & $63(15)$ & $134(15)$ & $197(15)$ \\
\hline Never breast fed & $7(2)$ & $42(5)$ & 49 (4) \\
\hline Still breast feed & $351(83)$ & $710(80)$ & $1061(81)$ \\
\hline \multicolumn{4}{|l|}{$\begin{array}{l}\text { Wanted status of child } \\
\text { during pregnancy }\end{array}$} \\
\hline Wanted during pregnancy & $295(70)$ & $676(76)$ & $970(74)$ \\
\hline Wanted later & $81(19)$ & $137(15)$ & $218(17)$ \\
\hline Not wanted & $45(11)$ & $73(8)$ & $118(9)$ \\
\hline \multicolumn{4}{|l|}{$\begin{array}{l}\text { Child delivered in a } \\
\text { health facility }\end{array}$} \\
\hline No & $292(69)$ & $541(61)$ & $833(64)$ \\
\hline Yes & $129(31)$ & $345(39)$ & $474(36)$ \\
\hline \multicolumn{4}{|l|}{ Size at birth } \\
\hline Above average & $154(37)$ & $277(31)$ & $430(33)$ \\
\hline Average & $153(36)$ & $383(43)$ & $536(41)$ \\
\hline Below average & $114(27)$ & $227(25.58)$ & $341(26.07)$ \\
\hline \multicolumn{4}{|l|}{ Index to birth history } \\
\hline Last birth & $402(96)$ & $845(95)$ & $1247(95)$ \\
\hline Not last birth & $19(4)$ & $41(5)$ & $60(5)$ \\
\hline
\end{tabular}




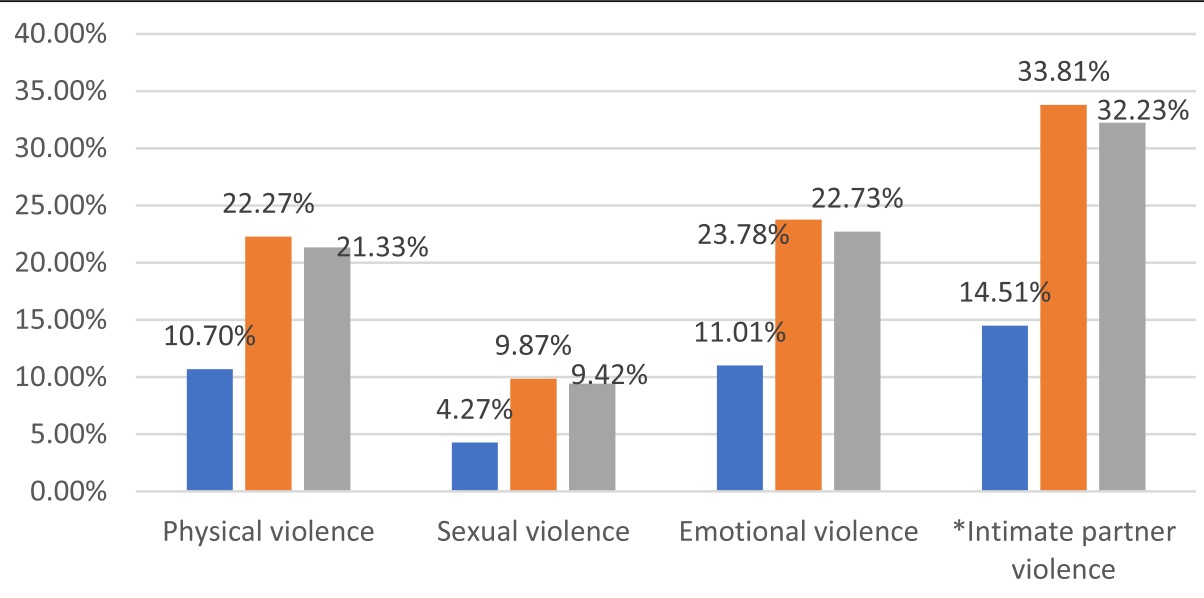

- Minimum acceptable diet received

- Did not receive minimum acceptable diet

- Overall

Fig. 4 *Experiencing either of the three violence types. Intimate partner violence among care givers of children aged between 6 to 23 months in Ethiopia, EDHS 2016

consequence on women helps to broaden perspectives in implementing nutrition-related programs. This finding is consistent with studies done in India [22], Bangladesh [23], and a systematic review that included many countries [24]. When women encounter violence from their partners, the care they provide for their children decreases. When violence happens, it has a persistent negative psychological effect on the victims [16, 24, 25], weakening the mother-child bond $[21,26]$ and making women less autonomous [11, 27]. When caregivers mind is occupied by negative thoughts that could be associated with some mental health problems, and their productivity and care to their children decrease. Women who faced intimate partner violence are more likely to abandon their children; this would prevent the child to get the appropriate care and nutrition he/she needs [24]. Finally, this would end up with malnutrition in the children and socioeconomic derangement to the society at large $[23,28,29]$.

Children of women who had secondary education were more likely to get a minimum acceptable diet than those who had no formal education. This is supported by studies done in Sri Lanka [30], Nepal [31], and Ethiopia [32]. Educated women are closer to media and have better awareness about child feeding practices and they could provide an appropriate diet for their children [33]. Most of the time, educated people live in urban areas where they could have better food and health care access with more work opportunities to support their families [34, 35].

Children of mothers who had a job outside of their home and were working during the survey were more likely to get a minimum acceptable diet than those who were not working. Having income helps women to have better participation in budgeting household expenditures in a way that positively influences [36] the variety and frequency of diet they provide for their children [30,37]. Moreover, this group of women could be more autonomous and educated and could make better decisions about household food consumption [32].

As compared to those who did not want to have more children, children of women who did not decide their future fertility were more likely to get a minimum acceptable diet. Women who did not decide could be in the dilemma of having more children or not. This feeling might happen due to the affection of their current children that possibly followed by better care and the provision of diversified and frequent meals.

Although this study considered nationwide data, all participating women were not interviewed for IPV, and information about IPV might not represent the national burden. Women were asked to recall an IPV happen within 12 months and there could be a tendency not to recall incidents and that would lead to underestimation of IPV. Also, recalling the food children fed would not be easy and cause misclassification of feeding practice, though it was minimized by using only a $24 \mathrm{~h}$ recall period. In addition, women could be shy to report as they encountered violence and that would lead to social desirability bias and underestimate the burden of IPV and thereby its effect on a minimum acceptable diet. Due to the cross-sectional nature of the data, temporality is still a concern. Although the status of getting a minimum acceptable diet was a more incident event and assessed using a $24 \mathrm{~h}$ recall 
Table 4 Factors associated with minimum acceptable diet among children aged 6 and 23 months in Ethiopia, EDHS 2016

\begin{tabular}{|c|c|c|c|c|}
\hline \multirow[t]{2}{*}{ Variables } & \multicolumn{3}{|c|}{ Minimum acceptable diet } & \multirow[t]{2}{*}{ AOR (95\% Cl) } \\
\hline & $\begin{array}{l}\text { Yes } \\
N(\%)\end{array}$ & $\begin{array}{l}\text { No } \\
\text { N (\%) }\end{array}$ & COR $(95 \% \mathrm{Cl})$ & \\
\hline \multicolumn{5}{|l|}{ Intimate partner violence } \\
\hline Yes & $16(4)$ & $406(96)$ & $0.33(0.15,0.74)$ & $0.35(0.16,0.77)$ \\
\hline No & $91(10)$ & $794(90)$ & 1.00 & 1.00 \\
\hline \multicolumn{5}{|l|}{ Residence } \\
\hline Urban & $33(22)$ & $118(78)$ & 1 & 1 \\
\hline Rural & $74(6)$ & $1082(94)$ & $0.24(0.11,0.57)$ & $0.74(0.14,3.87)$ \\
\hline \multicolumn{5}{|l|}{ Maternal Education } \\
\hline No formal education & $51(6)$ & $758(94)$ & 1.00 & 1 \\
\hline Primary education & $23(6)$ & 357 (94) & $0.96(0.46,2.02)$ & $0.89(0.43,1.85)$ \\
\hline Secondary education & $19(25)$ & $56(75)$ & $4.85(1.33,17.71)$ & $4.01(1.04,15.45)$ \\
\hline Higher education & $14(32)$ & $29(68)$ & $6.92(1.85,25.87)$ & $3.44(0.44,26.72)$ \\
\hline \multicolumn{5}{|l|}{ Wealth Index ${ }^{*}$} \\
\hline Poorest & $17(6)$ & $286(94)$ & 1.00 & 1 \\
\hline Poorer & $19(7)$ & $270(93)$ & $1.23(0.42,3.59)$ & $0.97(0.33,2.82)$ \\
\hline Middle & $20(7)$ & $260(93)$ & $1.30(0.41,4.10)$ & $1.15(0.38,3.52)$ \\
\hline Richer & $16(7)$ & $230(93)$ & $1.20(0.34,4.30)$ & $0.67(0.18,2.47)$ \\
\hline Richest & $35(18)$ & $154(82)$ & $3.87(1.40,10.73)$ & $0.68(0.11,4.18)$ \\
\hline \multicolumn{5}{|c|}{ Presence of other under five children in the house } \\
\hline Yes & $48(7)$ & $689(93)$ & $0.60(0.28,1.31)$ & $0.73(0.31,1.72)$ \\
\hline No & $59(10)$ & $511(90)$ & 1 & 1 \\
\hline \multicolumn{5}{|l|}{ Currently Breastfeeding } \\
\hline Yes & $97(9)$ & $964(91)$ & $3.49(0.68,17.92)$ & $4.36(0.69,27.56)$ \\
\hline No & $7(3)$ & $239(97)$ & 1.00 & 1 \\
\hline \multicolumn{5}{|l|}{ Fertility Desire } \\
\hline Want More children & $65(8)$ & $701(92)$ & $1.43(0.59,3.48)$ & $1.12(0.45,2.77)$ \\
\hline Undecided & $13(20)$ & $54(80)$ & $3.81(1.20,12.14)$ & $4.72(1.37,16.28)$ \\
\hline Don't Want any & $29(6)$ & $446(94)$ & 1.00 & 1.00 \\
\hline \multicolumn{5}{|c|}{ Mother worked outside home in the last 12 months } \\
\hline No & $43(6)$ & $690(94)$ & 1.00 & 1 \\
\hline Worked in 12 months & $16(7)$ & $218(93)$ & $1.25(0.35,3.82)$ & $1.25(0.40,3.91)$ \\
\hline Currently working & $48(14)$ & $292(86)$ & $2.68(1.21,5.90)$ & $2.26(1.01,5.11)$ \\
\hline \multicolumn{5}{|c|}{ Child delivered in a health facility } \\
\hline Yes & $53(11)$ & $421(89)$ & $1.80(0.89,3.66)$ & $0.79(0.39,1.60)$ \\
\hline No & $54(6)$ & $779(94)$ & 1.00 & 1.00 \\
\hline \multicolumn{5}{|l|}{ Media Exposure } \\
\hline Adequate & $44(17)$ & $211(83)$ & $3.32(1.65,6.65)$ & $2.29(0.92,5.67)$ \\
\hline In Adequate & $63(6)$ & 989 (94) & 1.00 & 1.00 \\
\hline
\end{tabular}

period, a reverse temporal relationship could not be precluded. Future researchers would bring more valid evidence and further understand the mechanism by conducting prospective studies that take into account the sensitiveness of the issue and possible mechanisms to handle it. Besides, implementations of nutritional programs need to take maternal partner violence into consideration. Addressing maternal situations could have its own impact on the strategies of halting childhood malnutrition. 


\section{Conclusion}

Overall, intimate partner violence against women had a negative association with the minimum acceptable diet children have received. Decreasing violence against women, educating, and increasing work opportunities for them would help in improving child feeding practice and reducing malnutrition and its consequences. Further studies that focus on possible community-based interventions aiming to decrease IPV are strongly recommended.

\begin{abstract}
Abbreviations
AOR: Adjusted Odds Ratio; BMI: Body Mass Index; COR: Crude Odds Ratio; CSA: Central Statistical Agency; DD: Dietary Diversity; EDHS: Ethiopian Demographic and Health Survey; IPV: Intimate Partner Violence; IYCF: Infant and Young Child Feeding; MDD: Minimum Dietary Diversity; MMF: Minimum Meal Frequency; OR: Odds Ratio; SD: Standard Deviation; WHO: World Health Organization
\end{abstract}

\section{Acknowledgments}

We would like to thank the central statistical agency for giving us permission to analyze the data.

\section{Authors' contributions}

DMT and ATT and conceptualized and designed the study and performed the data analysis and wrote the draft and final manuscripts; ZA and MY provided technical research guidance. All authors reviewed and approved the final manuscript.

\section{Funding}

No funding was available for this study.

\section{Availability of data and materials}

The datasets used and/or analyzed during the current study are available from the corresponding author on reasonable request.

\section{Ethics approval and consent to participate}

Ethical approval for the EDHS was obtained from the National Research Ethics Review Committee (NRERC) and all participants signed informed written consent. This particular study was approved by the Institutional Ethical Review Committee of Institute of Public Health at the University of Gondar and approval to analyze the secondary data for this manuscript was provided by the CSA or ORCMacro (Demographic and Health Survey).

\section{Consent for publication}

Not applicable.

\section{Competing interests}

The authors declare that they have no competing interests.

\section{Author details}

${ }^{1}$ Department of Anesthesia, School of Medicine, University of Gondar, College of Medicine and Health Sciences, Gondar, Ethiopia. ${ }^{2}$ Department of Health System and Policy, Institute of Public Health, University of Gondar, College of Medicine and Health Sciences, Gondar, Ethiopia. ${ }^{3}$ Department of Human Nutrition, Institute of Public Health, University of Gondar, College of Medicine and Health Sciences, Gondar, Ethiopia. ${ }^{4}$ Department of Epidemiology and Biostatistics, Institute of Public Health, University of Gondar, College of Medicine and Health Sciences, Gondar, Ethiopia.

Received: 10 January 2020 Accepted: 25 May 2020

Published online: 28 July 2020

\section{References}

1. Kennedy G, Ballard T, Dop M. Guidelines for measuring household and individual dietary diversity. In: Nutrition and Consumer Protection Division, Food and Agriculture Organization of the United Nations; 2013.

2. Arimend M, Ruel MT. Dietary diversity is associated with child nutritional status: evidence from 11 demographic and health surveys. JNutr. 2004;134:2579-85.
3. UNICEF. Global Nutrition Report. 2018

4. Central Statistical Agency (CSA) [Ethiopia]. Ethiopia Demographic and Health Survey 2016. Addis Ababa, Ethiopia, and Rockville, Maryland, USA: CSA and ICF; 2016

5. Saha KKFE, Alam DS, Ariffen SE, Persson LA, Rasmussen KM. Appropriate infant feeding practices result in better growth of infant and young children in rural Bangladish. Bangladesh Amj clin Nutr. 2008;87:1852-9.

6. Hop LTGR, Giay T, Sastroamidjojo S, Schultink W, Lang NT. Premature complementary feeding is associated with poorer growth of Vietnamese children. Vietnam J Nutr. 2000;130:2683-90.

7. Tegegne M, Sileshi S, Benti T, Teshome M, Woldie H. Factors associated with minimal meal frequency and dietary diversity practices among infants and young children in the predominantly agrarian society of bale zone, Southeast Ethiopia: a community based cross sectional study. Arch Public Health. 2017;75(53):1-11.

8. Hassan MM, Laraib A, Khalid F, Zafar MN, Khalid Z, Saleem A, et al. Feeding and Nutritional Requirements of Infants - Practices and Attitudes of Mothers. J Rawalpindi Med Coll Stud Suppl. 2016;20(S-2):133-6.

9. Solomon D, Aderaw Z, Tegegne TK. Minimum dietary diversity and associated factors among children aged 6-23 months in Addis Ababa. Ethiopia Int J Equity Health. 2017;16(181):1-9.

10. WHO. Global status report on violence prevention 2014.

11. Parys A-SV, Deschepper E, Michielsen K, Galle A, Roelens K, Temmerman M, et al. Intimate partner violence and psychosocial health, a cross-sectional study in a pregnant population. BMC Pregnancy Childbirth. 2015;15(278).

12. Ferraro AA. Anxious mothers need support to avoid emotional feeding of infants. J Nutr. 2019;149(5):703-4.

13. Frith AL, Ziaei S, Naved RT, Khan Al, Kabir I, Ekström E-C. Breast-feeding counselling mitigates the negative association of domestic violence on exclusive breast-feeding duration in rural Bangladesh. The MINIMat randomized trial. Public Health Nutr. 2017:1-9.

14. Islam MJ, Baird K, Mazerolle P, Broidy L. Exploring the influence of psychosocial factorson exclusive breastfeeding in Bangladesh. Arch Womens Ment Health. 2016

15. Lentz EC. Complicating narratives of women's food and nutrition insecurity: domestic violence in rural Bangladesh. World Dev. 2018;104(2018):271-80.

16. Yoo JA, Huang C-C. The effects of domestic violence on children's behavior problems: assessing the moderating roles of poverty and marital status. Child Youth Serv Rev. 2012;34(2012):2464-73.

17. Misch ES, Yount KM. Intimate partner violence and breastfeeding in Africa. Maternal Child Health. 2014;18:688-97.

18. Bhutta ZA, Das JK, Rizvi A, MFG e, Walker N, Horton S, et al. Evidence-based interventions for improvement of maternal and child nutrition: what can be done and at what cost? Lancet. 2013;382:452-77.

19. WHO. Indicators for assessing infant and young child feeding practices: conclusions of a consensus meeting held 6-8 November 2007 in Washington D.C. USA. 2008.

20. Croft TN, Aileen M, Marshall J, Allen CK, et al. Guide to DHS Statistics. ICF: Rockville; 2018.

21. Boeckel MG, Wagner A, Grassi-Oliveira R. The effects of intimate partner violence exposure on the maternal bond and PTSD symptoms of children. J Interpersonal Violence. 2017;32(7):1127-42.

22. Zureick-Brown S, Lavilla K, Yount KM. Intimate partner violence and infant feeding practices in India: a cross-sectional study. Matern Child Nutr. 2015; 11(4):792-802.

23. Rahman M, Poudel KC, Yasuoka J, Otsuka K, Yoshikawa K. Masamine Jimba. Maternal exposure to intimate partner violence and the risk of Undernutrition among children younger than 5 years in Bangladesh. Am J Public Health. 2012;102(7):1336-45.

24. Yount KM, DiGirolamo AM, Ramakrishnan U. Impacts of domestic violence on child growth and nutrition: a conceptual review of the pathways of influence. Soc Sci Med. 2011;72(2011):1534-54

25. McLearn KT, Minkovitz CS, Strobino DM, Marks E, Hou W. Maternal depressive symptoms at 2 to 4 months post partum and early parenting practices. Arch Pediatr Adolesc Med. 2006;160:279-84.

26. Levendosky AA, Huth-Bocks AC, Shapiro DL, Semel MA. The impact of domestic violence on the maternal-child relationship and preschool-age Children's functioning. J Fam Psychol. 2003;17(3):275-87.

27. Shroff MR, Griffiths PL, Suchindran C, Nagalla B, Vazir S, Bentley ME. Does maternal autonomy influence feeding practices and infant growth in rural India? Soc Sci Med. 2011;73(3):447-55. 
28. Sobkoviak RM, Yount KM, Halim N. Domestic violence and child nutrition in Liberia. Soc Sci Med. 2012;74(2012):103-11.

29. Ziaei S, Naved RT, Ekström EC. Women's exposure to intimate partner violence and child malnutrition: findings from demographic and health surveys in Bangladesh. Matern Child Nutr. 2014;10(3):347-59.

30. Senarath U, Godakandage SSP, Jayawickrama H, Siriwardena I, Dibley MJ. Determinants of inappropriate complementary feeding practices in young children in Sri Lanka: secondary data analysis of demographic and health survey 2006-2007. Maternal Child Nutr. 2012;8(1):60-77.

31. Gautam KP, Adhikari M, Khatri RB, Devkota MD. Determinants of infant and young child feeding practices in Rupandehi, Nepal. BMC Res Notes. 2016; 9(135):1-7.

32. Beyene M, Worku AG, Wassie MM. Dietary diversity, meal frequency and associated factors among infant and young children in Northwest Ethiopia: a cross- sectional study. BMC Public Health. 2015:15(1007):1-9.

33. Dangura D, Gebremedhin S. Dietary diversity and associated factors among children 6-23 months of age in Gorche district, Southern Ethiopia: Crosssectional study. BMC Pediatr. 2017;17(6):1-7.

34. Na M, Aguayo VM, Arimond M, Mustaphi P, Stewart CP. Predictors of complementary feeding practices in Afghanistan: analysis of the 2015 demographic and health survey. Matern Child Nutr. 2018;14(S4):e12696.

35. Aemro M, Mesele M, Birhanu Z, Atenafu A. Dietary diversity and meal frequency practices among infant and young children aged 6-23 months in Ethiopia: a secondary analysis of Ethiopian demographic and health survey 2011. J Nutr Metab. 2013;2013:8.

36. Peter R, Kumar KA. Mothers' caregiving resources and practices for children under 5 years in the slums of Hyderabad, India: a cross-sectional study. $J$ Public Health. 2014;3(3-4):254-65.

37. Ruel MT, Menon P. Child feeding practices are associated with child nutritional status in Latin America: innovative uses of the demographic and health surveys. J Nutr. 2002;132:1180-7.

\section{Publisher's Note}

Springer Nature remains neutral with regard to jurisdictional claims in published maps and institutional affiliations.

Ready to submit your research? Choose BMC and benefit from:

- fast, convenient online submission

- thorough peer review by experienced researchers in your field

- rapid publication on acceptance

- support for research data, including large and complex data types

- gold Open Access which fosters wider collaboration and increased citations

- maximum visibility for your research: over $100 \mathrm{M}$ website views per year

At $\mathrm{BMC}$, research is always in progress.

Learn more biomedcentral.com/submissions 